\title{
High School Debate: Elevating Students Critical Thinking into Hoax Prevention
}

\author{
Awliya Rahmi \\ Sultan Thaha Syaaifuddin Islamic State \\ University \\ Jambi, Indonesia \\ awliya@uinjambi.ac.id \\ Jamaluddin \\ Sultan Thaha Syaaifuddin Islamic State \\ University \\ Jambi, Indonesia \\ jamaluddin@uinjambi.ac.id
}

\begin{abstract}
This study aims at examining students' criticial thinking reflected in their argumentations in debate. It is also purposed to identify the further benefit of students critical thinking as fundamental manner to prevent hoax in any circumstances. This study observes 48 senior high school students (aged 14-17) who participate in Indonesian and English provincial debate competition in 2018 in Jambi Province. The observation is focused on the argumentation and idea constructed and delivered by the students related to debate motions and their position in debate. In this observational research, the researchers remark the argumentations of the debaters in every round and analyze them by referring to the debate principles. This research is also strengthen by personal interview with the students at the end of the debate round. The study reports that debate principles urges debaters to inquisively provide a reasonable justification, applicable solution and positive future impact for every motions to win the debate. Not only arranging clashes, they are also required to question the argumentation of the opposite team by applying the principles. The fact that the motions are impromptu stimulates the students to think substantially critical in elaborating ideas. This mechanism of thought simultaneously avoids them to sustain fake news in their argumentations. The debaters agree that the debate principles trains them to be well informed about every news they hear before spreading it. Not only in debate, this way of thinking genuinely impacts their lives, particularly in identifying the truth of a news.
\end{abstract}

Keywords- Critical Thinking, English Debate, School Debate, Hoax Prevention

\section{INTRODUCTION}

Technology and information development nowadays grow rapidly. These both aspects are influencing each other. As the development of technology moves to higher line, the development of information follows. One element of technology that triggers other elements growth is the access of internet. Internet allows people all over the world to connect each other seamlessly. Smartphone, along with social media are undoubtedly part of human life today. These devices are helpful yet threatening.

The growth of ASEAN today is also a good impact of technology and information development. The development of education and information in ASEAN is enlarging in both quantitiy and accessibility [1]. Many countries in ASEAN are reaching their better condition in some aspects such as education, economy, tourism, etc. As ASEAN is facing the great periode of development, another erratic effect follows.

Hoax or fake news is the real traiter to the development of nations. It is defined as news article that are intentionally and verifiably false, and could mislead readers [2]. As information distributes swiftly, fake news pursues. Government as policy maker, civil society and business community have to work seriously to optimize the advantage of technology and information development [1]. Hoax spreads effortlessly through social media. Continuously, it is believed to be true by some people. The worst reaction of hoax is that it brings about hatred, provocation and disintegration among society. Despite of that, people can prevent the spread of fake news in some strategies. Instead of restricting the use of technology and information, educating people to have critical thinking is considered more effective. To support this, school can provide their students with debating where students are simulated to take on roles in government as a policy maker [3].

High school debate is regarded as one of strategies to stimulate students critical thinking. This educative strategy is agreed to increase people's ability to distinguish fact from fiction [2]. Debate as stated by Tumposky is able to nurture students critical thinking skills and awareness of thought, facilitate In Jambi Province, High School debate is an annual events held by department of education. This event invites all regencies in Jambi Province to delegate one English debate team and one Indonesian debate tim. In Jambi Provincial High School Debate 2018, there were 20 teams (60 debaters) competed in English and Indonesian debate competition. The debate applied Asian parliamentary system. To be th winner of debate competition, debaters ought to perform the best argument following the debating principles. Rules of debate require students to have logic and rational argumentation. In other words, they are prohibited to deliver fake and irrational information.

Debating principle is a key concept to have a good quality of a debate. Generally, debaters require to define and contextualize the motion of debate build and prove their arguments. These principles set the debaters to observe any motions of debate from many perspectives. Students who do debate get used to see many cases in two-sided perspective. This perspective is, however, a great way to train students to investigate truth and good side of any cases. By having debater's point of view, students will be prevented from 
believing fake news easily or spreading fake news without clarification.

Many experts studied about how debate is advantageous for students. Many researchers related to debate had been conducted by experts in various major. Generally, the researches ended up with the result that students debate is positively effective to improve students public speaking skill. On their research, Rohmatika and Rois found that the AREL (Assertion, Reasoning, Evidence and Link-back) in aranging debate argument improve students skill of debate after two layers of test [4]. On another research, Oros obesreved SCDs (Structured Classroom Debates) and resulted that debate can encourage students participation and critical thinking [5]. In addition, Darby in his previous observation to his graduate and undergraduate students found that debate is very useful to prepare students for roles as leaders, organizers and advocate [6]. Most of debate research corelates debate to the improvement of students public speaking and critical thinking. Not many research investigates profoundly the advantage of having critical thinking as astrategy to maintain sustainable development. Therefore, the concern of this study is to describe how high school debate can initiate students critical thinking, lead students to prevent hoax and beneficially sustain development of a nation.

\section{Methodology}

In this observational qualitative study because it uses a wide array of empirical materials such as interviews, observation and document analysis [7]. The data were collected by using recording and note taking technique. To gather information about how students arrange their arguments following the debating priciples, researchers took some notes, watched students performances and had discussion with the juries. In addition, researchers also had a comprehensive interview with students to discover how debate affected their mindset about various issues.

\section{RESULTS}

High school debate is essentially different from major debate which happens without certain preparation and mechanisim. On this research, the debate uses Asian parliamentary system. There are two teams in one debate round. A team consists of three speakers with different roles. Some students (debaters) admitted that their ipinion about debate totally changed after they participated in high school debate. The rules of debate and the adjudication system encourage them to build analytical arguments. Another significant aspect of debate is the motion of debate tself. It is common that the motions in debate are given spontaneous. In other words, the motions are given unrehearsed. The point is, students must be aware of any possible current issues all over the world. Not only that, they also require to always have two angels of the case.

\section{A. Debating Principles:Strategies to Enhance Student's Critical Thinking}

Debating principles are core of the debate. By not following these principles, the debate cannot reach its fundamental function, enhancing students critical learning. There are at least three main principles that must be obeyed by students to build strong and unbreakable arguments.

\section{1) Defining Motion}

In one debate round, two teams will be splitted into two different position: affirmative/goverment and negative/opposition. To start the debate, the first speaker form affirmative team will define the motion to set clear parameter of the debate itself. Some students think that they have to describe the meaning of every words written in the motion but it is actually an incorrect perception. It is necessary for students to build a fair and clear interpretation of the motion, considering that the definition will be the core of the whole debate.

One of motions given in Jambi provincial high school debate this year was 'This House Would incentivize mother to abort a baby'. Those who are non-debater students will have tendency to straightly say no to this motion. In a debate, a team cannot choose whether they want to agree with this motion or not. Instead of that, they must be prepared to any possible position they will be given. Related to this motion, it is important for students to find the key words of it and set the interpretation.

\section{2) Motion Contextualization}

After motion is interpreted and defined, students must contextualize it. Contextualization can be considered as an essential part of motion definition. It is the historical background of the motion. In addition, contextualization is the factual reason why goverment needs to take an action about the case. Students need to put the status quo as refference. It is all policies surrounding the case.

In a debate under the motion 'This House Would incentivize mother to abort a baby'. The first speaker from affirmative team gave a criminal-based contextualization. She believed that this motion was proposed due to the raising of criminal actors. As reaction to this problem, government created and developed a device to identify the future of fetus inside the womb. The future means here is whether the fetus will grow up as criminal actor such as murderer, thief, robber, etc. She also added that this is a great preventive action to minimize crime.

\section{3) Arguments, Rebuttals and Research}

Debate is a media to propose and against arguments. Thus, not only define and contextualize the motions, students must also bring up their arguments related to the motion given. Arguments are defined as a group of two or more propositions that express an inference [8]. Arguments and rebuttls are basically similar. Inspite of that, rebuttels is regarderd as the negative form of rebuttals. As when a speaker say ' $\mathrm{A}$ is the best sollution' then rebuttal will be 'A is not the best solution'. Arranging arguments in debate can help students advance particular skills. It is because debate is in building arguments, there is one popular formulation which is applied by debaters. Arguments and rebuttals must be composed following AREL structure. It stands for Assertion, Reasoning, Evidence and Link-back. Generally, debaters ought to begin their arguments by stating or emphasizing a premise which is then supported by reason of it. Not only that, evidence is required to strengthen their arguments. Arguments should be ended with a conclusion. 


\section{B. Critical Thinking: A Key to Hoax Prevention}

In order to deal with the spreading of uncontrolable fake news, an encouragement to critical thinking urges to do. The main cause of hoax is that society are too easy to believe in news spreaded. Besides that, the tendention to believe in what most people do instead of what evidence brings up can also mislead society to unconsciously believe in fake news [9]. It is impossible to limit the use of technology and internet of the society to stop this case. Thus, enchancing critical thinking to students is regarded an excessive prevention. One of the basic strategies used to enhance critical thinking is classroom instruction.

\section{Initiating Students to Truth Investigation}

The core value of having critical thinking is willingness to investigate truth based on evidence. Information literacy is an aspect or dimension of critical thinking [11]. Meanwhile, many people still occupy in the concept of 'If most people believe in that or do that, then, that is correct'. Unfortunately, this perspective, which is not evidence-based is an old tradition that society need to leave behind. Introducing students to debate is beneficial to cultivate the value of seeking truth and evidence.

The AREL structure of arguments in debate principles urges students to provide evidence in their speech. Ideas which are not supported by proofs are considered weak. Before the debate begins, students are given 30 minutes of time to build the case and arguments. In that period of time, students are allowed to discuss with other members of their own team about the motion. They can also share ideas or evidence to accomplish the AREL requirement for idea elaboration. The fact that all the participants of the competitions are not allowed to use any electronic device is also another fundamental reason why students must get themselves aware to current national and international issues. As understanding the case on surface is not enough, students must also be well informed about factual condition related to issues. This is however a positive beginning for students to have proof-based perspective.

Encouraging Students to be Intelligent News Spreader

As students are well informed about the fact behind news, they will be more selective and careful in spreading the news. This manner will bring up positive and continuous impact to fake news problems. Hoax can only be managed by the spreader. Intelligent reader will investigate the reality first and then decide whether the news is worth to share or not.

Debaters, the evidence-based thinker, fully understand about the effect of spreading fake news. Generally, hoax are written biased and sloppy. It also contains propaganda, satire and hatred which are the real thread for social tranquility. However, propaganda and hatred are the main causes of social disruption. Hoax can also be exploited to manipulate public opinion [12]. Not only it harms people but spreading fake news also harms students themselves as intellectual actor. One of intelectual actor's roles is as the agent of change. In this case, an intelectual actor is expected to reconstruct the way of thinking from 'most-believed (or done) based truth' to 'evidence-based truth'. Nontheless, spreading news without firstly confirming the truth is regarded disgrace and students make effort to avoid that

\section{DISCUSSION}

\section{A. Critical Students to Open Minded Citizen: An Asset to Sustainable Development}

To be critical thinker is a long term process and involves some aspects such as biological, cultural and social aspects. These young boys and girls are now just teenagers and high school students, but soon they leave school they will socialize and join the society. Today generation is undeniable going to be the next leader or government in several years and play various roles in society. If they are not prepared to be an open minded thinker, then it is obvious what kind of leaders, organizers, teachers, advocates or any other roles people will have. As leader is the decision maker in a country or organization, he or she must be open minded. It is to prevent them from taking biased and unreasonable decision.Motions given in debate are mostly about social, economical and cultural issues. Those issues are considered fundemantal for development of a country. It is substantial to introduce students to these important social matters.

It can't be denied that today is the era of unlimited networks with unlimited points of view. Under the reason of human right, people have desire to speak up everything on their mind. This situation is a two-sided knife for a nation. Firstly, it is good for a nation to have the citizen's attention. Unfortunately, it will be harmful for nation if the spreading issue is not a proof-based. Critical student, as the agent of change, is an asset to sustain the development of a country. As fake news can mislead society to disagreement and destruction, critical thinking is the best weapon that society must own. It can prevent society form logical fallacy which is in the contrary of critical thinking and also the root of fske news story. A great country is not only managed by a leader, but it must be supported by the citizens. The problem is, if the citizen is unstable or split up, the \{Citation\} development of a country will be postponed. Open minded citizens have strong and reasonable perspective of any cases. It makes them not easly provoked by hoax. However, encouraging students to have critical thinking also means preparing open minded citizens in the future.

\section{CONCLUSION}

Living in the era where the 'share' button can do many things is exciting yet terrifying. One of disadvantages that threatens the sustainability of country development is the spreading of hoax or fake news. Not only it can bring up wrong values but it can also mislead society into disunity. High school debate had been observed to be a preventive solution for hoax issue. Since high school debate is systematical and adjudicated, it is considered as a good training for students to have critical thinking. Generally, debate initiates students to investigate truth and fact behind every cases. Having critical thinking is not only beneficial for students themselves but also for country. The core of country development is the unity of the citizen which is now threatened by the spread of fake news containing propaganda and hatred. Government cannot control the internet but they can educate the users. Finally, high school debate is a form of education given to students to encourage their critical thinking in order to prepare them to be open minded citizens. 


\section{REFERENCES}

[1] Mansell, Robin and Wehn Uta, Knowledge societies: Information technology for sustainable development (New York: United Nations Publications, 1998)

[2] Allcott, Hunt and Gentzkow, Matthew "Social media and fake news in the 2016 election," Journal of Economic Perspectives 31, no. 2 (2017): 213.

[3] Ogle, Donna, Klemp, Ron and McBride, Bill Building literacy in social studies : strategies for improving comprehension and critical thinking (Danvers: Association for Supervision and Curriculum Development (ASCD), 2007)

[4] Rohmatika, Arina and Syamsuddin, "Penggunaan AREL pada Penyampaian Argumen di Klub Debat Bahasa Inggris STKIP PGRI Ponorogo," Dinamika Ilmu 14, no. 2 (2014): 162.

[5] Oros, Andrew L. "Let's debate: Active learning encourages student participation and critical thinking," Journal of Political Science Education 3, no. 3 (2007): 293.

[6] Darby, Michele "Debate: A teaching-learning strategy for developing competence in communication and critical thinking," Journal of Dental Hygiene 81, no. 4 (2007): 1.
[7] Eunice M. Aclan dan Noor Hashima Abdul Aziz, "Why and how EFL students learn vocabulary in parliamentary debate class," Advances in Language and Literary Studies 6, no. 1 (2015): 3.

[8] Crews-Anderson, Timothy A. Critical thinking and informal logic (New York: Humanities-Ebooks, 2007)

[9] Cohen, Elliot D. Critical Thinking Unleashed (Lanham, Md: Rowman \& Littlefield Publishers, 2009), 2.

[10] McMillan, James H. "Enhancing college students' critical thinking: A review of studies," Research in higher education 26, no. 1 (1987): 4.

[11] Paul, Richard and Elder, Linda Critical Thinking Competency Standards (For Educators) (Tomales, CA: Foundation for Critical Thinking, 2007)

[12] Shu, Kai et al., "Fake news detection on social media: A data mining perspective," ACM SIGKDD Explorations Newsletter 19, no. 1 (2017): 2.

[13] Moon, Jennifer A. Critical Thinking: An Exploration of Theory and Practice (London; New York: Routledge, 2008), 95. 